\title{
Thyroid Hormones in Human Milk and their Influence on Thyroid Function of Breast-Fed Babies
}

\author{
HITOSHI MIZUTA, NOBUYUKI AMINO, KIYOSHI ICHIHARA, TOKUZO HARADA, OSAMU NOSE, \\ OSAMU TANIZAWA, AND KIYOSHI MIYAI ${ }^{(18)}$ \\ Central Laboratory for Clinical Investigation, Department of Laboratory Medicine [H. M., N. A., K. I., K. M.], \\ Department of Pediatrics [T. H., O. N.], and Department of Obstetrics and Gynecology [O. T.], Osaka University \\ Hospital, Osaka, Japan
}

\begin{abstract}
Summary
Various assay methods for detection of thyroid hormones in human milk were evaluated in recovery and dilution experiments after which the concentrations of thyroxine $\left(T_{4}\right)$ and $3,5,3^{\prime}$-triiodothyronine $\left(T_{3}\right)$ were measured and compared with those in serum. The effect of breast feeding on pituitary thyroid function of normal babies also was studied. Competitive protein-binding analysis (CPBA) was found to be unsuitable for measurement of $T_{4}$ in milk. $T_{4}$ was not detected in samples of human milk by four radioimmunoassays (RIA), although more than $100 \%$ of $T_{4}$ was recovered in the assays. RIA (double antibody-ANS system) seemed to be reliable for detection of $T_{3}$ in milk, judging from recovery and dilution experiments. $T_{3}$ was detectable in all samples obtained 1-4 months postpartum. The $T_{3}$ concentration in milk was not correlated with protein concentration or daily volume. The concentration of $T_{3}$ in milk was lower than that in serum and the mean ratio of serum $T_{3}$ to milk $T_{3}$ was $2.8 \pm 1.7$ (mean \pm S.D.). No correlation was observed between the $T_{3}$ concentration or daily $T_{3}$ excretion in milk and the $T_{3}$ concentration in serum. The total amount of $T_{3}$ excreted in milk was estimated as only 5 $1000 \mathrm{ng} / \mathrm{day}$. The serum levels of thyrotropin, $T_{4}$, free $T_{4}$ and $T_{3}$ were not significantly different between breast-fed and bottle-fed babies. These results indicate that $T_{3}$ excretion in milk cannot be explained by simple diffusion from the blood into the mother's milk and that breast feeding has no influence on the pituitary thyroid axis of normal babies.
\end{abstract}

\section{Abbreviations}

CPBA, competitive protein-binding analysis

RIA, radioimmunoassay

ANS, 8-anilinonaphthaline sulfonic acid

TBG, thyroxine-binding globulin

Although breast-feeding has been suggested to improve the clinical course of congenital hypothyroidism (1), discrepant results have been obtained on the concentrations of thyroid hormones in human milk (1, 9-11, 13-15). Very recently Letarte et al. (3) reported that breast feeding had no protective effect against the deleterious effects of congenital hypothyroidism. In this study we examined the performance characteristics of various methods of assaying thyroid hormones in human milk and report the measurements of concentrations of thyroxine $\left(\mathrm{T}_{4}\right)$ and 3,5,3'-triiodothyronine $\left(T_{3}\right)$ using these assays. We also examined the relationship of thyroid hormone concentrations in milk and serum and the effect of breast feeding on the pituitary-thyroid axis of normal babies.

\section{MATERIALS AND METHODS}

Human milk was obtained from three healthy women and 18 patients with thyroid diseases between 7 days and 7 months after delivery. The patients included 11 women with Graves' disease, 6 with Hashimoto's disease and one with simple goiter. None of the patients with Graves' disease were receiving anti-thyroid drugs at the time of examination. Serum samples were obtained at the same time from all subjects. For estimation of daily $T_{3}$ excretion in milk, 24-h samples were collected from 16 patients with thyroid disease 1-4 months postpartum. The $\mathrm{T}_{3}$ concentration and total volume were measured. Serum samples were collected from breastfed and 10 bottle-fed normal babies aged about 1 month. All milk and serum samples were frozen at $-20^{\circ} \mathrm{C}$ until assayed.

$\mathrm{T}_{4}$ concentrations in milk were measured by the following methods using commercial kits: (1) CPBA; Method A, ethanol extraction and separation of adsorbing-granules (Thyopac 4 , The Radiochemical Centre, Buckinghamshire, England); Method B, ethanol extraction and separation of resin sponge (Tetrasorb-125, Dainabott Radioisotope Laboratories, Tokyo, Japan); Method C, alkaline extraction and separation of Sephadex column (Tetralute, Ames Company, Elkhart): (2) radioimmunoassay (RIA) (method of bound/free separation and inhibition of $\mathrm{T}_{4}$-TBG binding are described); Method $D$, double antibody and 8-anilinonaphthalene sulfonic acid (ANS) (T 4 RIA kit, Eiken Immunochemical Laboratory, Tokyo, Japan); Method $E$, adsorbing granules and thiomersalate ( $\mathrm{T}_{4}$ RIA PAC, Radiochemical Center, Buckinghamshire, England); Method F, polyethylene glycol and ANS (T ${ }_{4}$ RIA KIT II, Dainabott Radioisotope Laboratory, Tokyo, Japan); Method $G$, Sephadex column and alkaline buffer (Seralute, Ames Company, Elkhart).

The standard $\mathrm{T}_{4}$ solution was prepared by dissolving $\mathrm{L}_{-} \mathrm{T}_{4}$ (sodium salt, Sigma Chemical) in $0.1 \mathrm{~N} \mathrm{NaOH}$ solution and diluting it with phosphate buffered saline ( $\mathrm{pH} \mathrm{7.5)} \mathrm{containing}$ $0.25 \%$ bovine serum albumin. For measurement of milk $\mathrm{T}_{4}$ using Methods C-G, $1 \mathrm{ml}$ of standard $\mathrm{T}_{4}$ solution or $1 \mathrm{ml}$ of milk was extracted with $2 \mathrm{ml}$ of $99.5 \%$ ethanol, and the mixture was centrifuged at $2000 \times g$ at $4^{\circ} \mathrm{C}$ for $10 \mathrm{~min}$. Then the ethanol fraction obtained was evaporated and the dried sample was dissolved in $1 \mathrm{ml}$ of thyroid hormone-free serum and assayed for $\mathrm{T}_{4}$. The thyroid hormone-free serum was prepared from pooled normal human serum by removing endogenous $T_{4}$ and $T_{3}$ by treatment with charcoal (6).

$\mathrm{T}_{3}$ concentrations in milk was measured by double antibody radioimmunoassay, which used ANS for inhibition of $T_{3}$-TBG binding $\left(\mathrm{T}_{3}\right.$ RIA kit Eiken Immunochemical Laboratory, Tokyo, Japan). The standard $T_{3}$ solution was prepared by dissolving $L-T_{3}$ (sodium salt, Sigma Chemical) in $0.1 \mathrm{~N} \mathrm{NaOH}$ solution and diluting it with thyroid hormone-free serum. $\mathrm{T}_{3}$ standard solutions 
or milk samples were extracted with ethanol as described above and the dried extracts were dissolved in thyroid hormone-free serum for $\mathrm{T}_{3}$ assay.

Recovery experiments were conducted by mixing aliquots of standard $T_{4}$ or $T_{3}$ solution with milk and then measuring the $T_{4}$ or $\mathrm{T}_{3}$ concentrations as described above. After skimming off the lipid, protein concentrations in milk were measured by the method of Lowry et al. (14).

Serum concentrations of thyrotropin (TSH RIA kit, Daiichi
Radioisotope Laboratories, Tokyo, Japan), $\mathrm{T}_{4}$ and $\mathrm{T}_{3}\left(\mathrm{~T}_{4}\right.$ RIA kit, $\mathrm{T}_{3}$ RIA kit Eiken Immunochemical Laboratory, Tokyo, Japan) were measured by double antibody RIA and free $T_{4}$ was measured by solid-phase RIA (Gamma Coat Free $\mathrm{T}_{4}$ RIA kit, Travenol Laboratories, Massachusetts, USA).

\section{RESULTS}

The recoveries of $\left[{ }^{125} \mathrm{I}\right]-\Upsilon_{4}$ and $\left[{ }^{125} \mathrm{I}\right]-\mathrm{T}_{3}$ in the ethanol extraction were $91.9 \pm 0.05 \%$ and $89.5 \pm 0.63 \%$ (mean \pm S.D.), respectively.

Table 1. Concentration of $T_{4}$ in human milk measured by various methods

\begin{tabular}{|c|c|c|c|c|c|c|c|c|c|c|}
\hline \multirow[b]{3}{*}{$\begin{array}{l}\text { Case } \\
\text { No. }\end{array}$} & \multirow[b]{3}{*}{ Diagnosis } & \multirow{3}{*}{$\begin{array}{c}\text { Time of } \\
\text { sampling } \\
\text { (postpartum) }\end{array}$} & \multirow{3}{*}{$\begin{array}{l}\text { Serum } \\
\text { concen- } \\
\text { tration } \\
(\mu \mathrm{g} / \mathrm{dl})\end{array}$} & \multicolumn{7}{|c|}{ Milk concentration $(\mu \mathrm{g} / \mathrm{dl})$} \\
\hline & & & & \multicolumn{3}{|c|}{$\begin{array}{l}\text { Competitive protein- } \\
\text { binding assay }\end{array}$} & \multicolumn{4}{|c|}{ Radioimmunoassay } \\
\hline & & & & $\begin{array}{c}\text { Method }^{2} \\
\text { A }\end{array}$ & $\begin{array}{l}\text { Method } \\
\text { B }\end{array}$ & $\begin{array}{l}\text { Method } \\
\text { C }\end{array}$ & $\begin{array}{l}\text { Method } \\
\text { D }\end{array}$ & $\begin{array}{l}\text { Method } \\
\text { E }\end{array}$ & $\begin{array}{l}\text { Method } \\
\text { F }\end{array}$ & $\begin{array}{l}\text { Method } \\
\text { G }\end{array}$ \\
\hline 1 & Normal & 6 days & 8.8 & 49.7 & 25.1 & 3.8 & $<0.7$ & $<0.7$ & $<0.7$ & $<1.5$ \\
\hline 2 & Normal & 25 days & 6.0 & 46.3 & 33.7 & 4.9 & $<0.7$ & $<0.7$ & $<0.7$ & $<1.5$ \\
\hline 3 & Normal & 2 months & 7.7 & 49.3 & 9.3 & 8.6 & $<0.7$ & $<0.7$ & $<0.7$ & $<1.5$ \\
\hline 4 & $\begin{array}{l}\text { Graves' } \\
\text { disease }\end{array}$ & 7 days & 24.0 & 33.9 & 49.9 & 5.2 & $<0.7$ & 0.7 & 0.7 & $<1.5$ \\
\hline 5 & $\begin{array}{l}\text { Hashimoto's } \\
\text { disease }\end{array}$ & 7 months & 4.5 & 46.7 & 29.8 & 3.2 & $<0.7$ & $<0.7$ & 0.7 & $<1.5$ \\
\hline
\end{tabular}

${ }^{1}$ Serum $\mathrm{T}_{4}$ was measured by Method D (see "Materials and Methods" in the text). Normal range 5.0-11.0 $\mu \mathrm{g} / \mathrm{dl}$.

${ }^{2}$ Method A-G, see "Materials and Methods" in the text.

Table 2. Recovery of $T_{4}$ added to human milk in various assays

\begin{tabular}{|c|c|c|c|c|c|}
\hline \multirow{2}{*}{$\begin{array}{c}\text { Assay } \\
\text { method }^{1}\end{array}$} & \multirow{2}{*}{$\begin{array}{c}\mathrm{T}_{4} \\
\text { concentration } \\
\text { in milk } \\
(\mu \mathrm{g} / \mathrm{dl})\end{array}$} & \multirow{2}{*}{$\begin{array}{c}\mathrm{T}_{4} \\
\text { added } \\
\text { to milk } \\
(\mu \mathrm{g} / \mathrm{dl}) \\
\end{array}$} & \multirow{2}{*}{$\begin{array}{c}\text { Measured } \\
\text { value } \\
(\mu \mathrm{g} / \mathrm{dl})\end{array}$} & \multicolumn{2}{|c|}{ Recovery $(\%)^{2}$} \\
\hline & & & & Individual & Mean \pm S.D. \\
\hline \multirow[t]{2}{*}{$\mathrm{t} A$} & 49.4 & 3.2 & 50.4 & 31 & \\
\hline & 49.4 & 6.3 & 54.3 & 78 & $94 \pm 49$ \\
\hline \multirow[t]{4}{*}{ B } & 9.3 & 3.2 & 19.6 & 329 & \\
\hline & 9.3 & 6.3 & 27.9 & 297 & $333 \pm 24$ \\
\hline & 9.3 & 12.5 & 52.5 & 343 & \\
\hline & 9.3 & 25.0 & $>100$ & $>363^{3}$ & \\
\hline \multirow[t]{2}{*}{$\mathrm{C}$} & 8.6 & 3.2 & 11.5 & 92 & \\
\hline & 8.6 & 6.3 & 13.8 & 83 & $93 \pm 9.8$ \\
\hline \multirow{3}{*}{$\mathrm{D}$} & $<0.7$ & 6.3 & 11.0 & 176 & $161 \pm 64$ \\
\hline & $<0.7$ & 12.5 & 17.6 & 141 & \\
\hline & $<0.7$ & 25.0 & 22.0 & 88 & \\
\hline \multirow[t]{4}{*}{$\mathrm{E}$} & $<0.7$ & 3.2 & 4.2 & 131 & \\
\hline & $<0.7$ & 6.3 & 6.9 & 112 & \\
\hline & $<0.7$ & 12.5 & 16.6 & 132 & $129 \pm 13$ \\
\hline & $<0.7$ & 25.0 & 34.5 & 142 & \\
\hline \multirow[t]{4}{*}{$\mathrm{F}$} & $<0.7$ & 3.2 & 4.8 & 153 & \\
\hline & $<0.7$ & 6.3 & 5.7 & 90 & $115 \pm 29$ \\
\hline & $<0.7$ & 12.5 & 15.3 & 122 & \\
\hline & $<0.7$ & 25.0 & 23.6 & 94 & \\
\hline \multirow[t]{2}{*}{ G } & $<1.5$ & 3.1 & 3.3 & 107 & \\
\hline & $<1.5$ & 6.2 & 10.0 & 160 & $158 \pm 37$ \\
\hline
\end{tabular}

'See "Materials and Methods."

${ }^{2}$ In calculation of recovery, undetectable levels were taken as $0 \mathrm{ng} / \mathrm{dl}$.

${ }^{3}$ Percent recovery was more than $363 \%$ and in calculation of mean \% recovery $363 \%$ was taken as recovery. 
The results of measuring $\mathrm{T}_{4}$ concentration in human milk by various methods are summarized in Table 1. Values from 3.2-49.9 $\mu \mathrm{g} / \mathrm{dl}$ were obtained by CPBA, but values obtained using RIA were $\leq 0.7 \mu \mathrm{g} / \mathrm{dl}$. Recovery data are shown in Table 2 . Results varied considerably: mean values ranging from 93-333\%. Furthermore, the dilution curves of milk samples were not parallel with the standard curve in any of the three CPBA assays. Results were also unsatisfactory when skimmed milk was used instead of whole milk.

On the other hand, $T_{3}$ concentration in milk was consistently measured by RIA. The mean \% recoveries of $\mathrm{T}_{3}$ added to two samples of human milk were 100.7 and $93.7 \%$ (Table 3). The dilution curves of milk samples were parallel with the standard curve (Fig. 1). Results of the $T_{3}$ concentrations in various samples of human milk are shown in Table 4. All the milk samples obtained 1-4 months postpartum had detectable $T_{3}$, but the concentrations were lower than those in serum, and the ratio of serum $\mathrm{T}_{3}$ to milk $\mathrm{T}_{3}$ was $2.8 \pm 1.7$ (mean \pm S.D.). No correlation was observed between the $T_{3}$ concentration or daily $T_{3}$ excretion in milk and the $T_{3}$ concentration or free $T_{3}$ index in serum. The $T_{3}$ concentration in milk was not correlated with protein concentration or daily volume of milk. The total daily amounts of $\mathbf{T}_{3}$ excreted in milk were estimated as 5-1000 ng.

As shown in Table 5, there were no significant differences in serum levels of thyrotropin, $T_{4}$, free $T_{4}$ and $T_{3}$ between breast-fed and bottle-fed babies.

\section{DISCUSSION}

Discrepant results have been reported for the thyroid hormone concentration in human milk. Earlier publications $(13,14)$ reported $\mathrm{T}_{4}$ concentrations in milk proportional to those in human serum measured by CPBA (Method B in this study). Sack et al. $(9,10)$ reported similar levels of $\mathrm{T}_{4}$ in milk obtained 8-48 days after delivery, he used a RIA similar to Method $F$ in this study. In later studies, little or no $T_{4}$ was detected in human milk by RIA $(1,11,15)$. These discrepancies are due probably to methodologic differences. The reliability of $\mathrm{T}_{4}$ and $\mathrm{T}_{3}$ assay in milk was examined by recovery experiments in only one earlier study (7).

Our study showed that the CPBA methods were unsuitable for the measurement of $T_{4}$ in milk because the \% recovery of added $\mathrm{T}_{4}$ varied among the several methods and the dilution curves were not parallel with the standard curves. On the other hand, the reliability of the RIA method was also not clear because the recoveries of $\mathrm{T}_{4}$ added to milk exceeded $100 \%$, although the recovery of $\left[{ }^{125} \mathrm{I}\right]-\mathrm{T}_{4}$ in the ethanol extraction was about $90 \%$. Fatty acid seems to interfere in CPBA but not in RIA (12). The mechanism of positive interference in RIA is not clear. Because $T_{4}$ was not detectable in milk by RIA, the data suggest that the $T_{4}$ level $\ln$ milk is very low. This suggestion is in agreement with results of animal experiments, which showed that little $T_{4}$ was transferred from the mother to sucklings $(8,16)$ and with human data showing extremely low levels of butanol-extractable iodine in human milk (5).

Reported data on milk $T_{3}$ concentrations also have been con- flicting. Bode et al. (1) and Varma et al. (15) reported higher $\mathrm{T}_{3}$ levels in milk than in normal serum: measurements were made using ethanol extraction. On the contrary, Sato and Suzuki (11) reported very low levels of $T_{3}$ in unextracted milk. The mean values approximated one-tenth the serum concentrations. In the present study, $T_{3}$ RIA (double antibody-ANS system) seemed to be reliable for measurement of milk $T_{3}$ judging from the recovery and dilution experiments. We used dried samples after extraction with ethanol as reported by Bode et al. (1). In earlier reports (1, $10,15)$ the reliability of the method for detection of milk $T_{3}$ was not examined by recovery experiments; in contrast, we obtained good results in recovery and dilution experiments.

The mechanism(s) of $T_{3}$ secretion in milk is not clear. Iodine is known to be actively concentrated by mammary tissue and considerable quantities of iodine are secreted in milk $(2,5,8)$. It has been shown that more than $99 \%$ of the thyroid hormones in serum are bound to thyroxine-binding proteins. More than $60 \%$ of the iodine in rat milk is bound to protein (8). Our preliminary study revealed no detectable TBG in human milk (unpublished data). Furthermore, we found no correlation between the $T_{3}$ and protein concentration in human milk. It is unlikely that $T_{3}$ is actively concentrated from blood, synthesized from iodine, or derived from $T_{4}$ in the mammary gland because the $T_{3}$ concentration in milk was lower than that in serum in all samples. Assuming that serum $T_{3}$ is transferred to milk by simple diffusion, the milk $T_{3}$ concentration might be expected to relate to the $T_{3}$ or free $T_{3}$ level in serum. To assess this possibility we compared $T_{3}$ and free $T_{3}$ index levels with milk $T_{3}$ concentrations in lactati.ng patients with var-

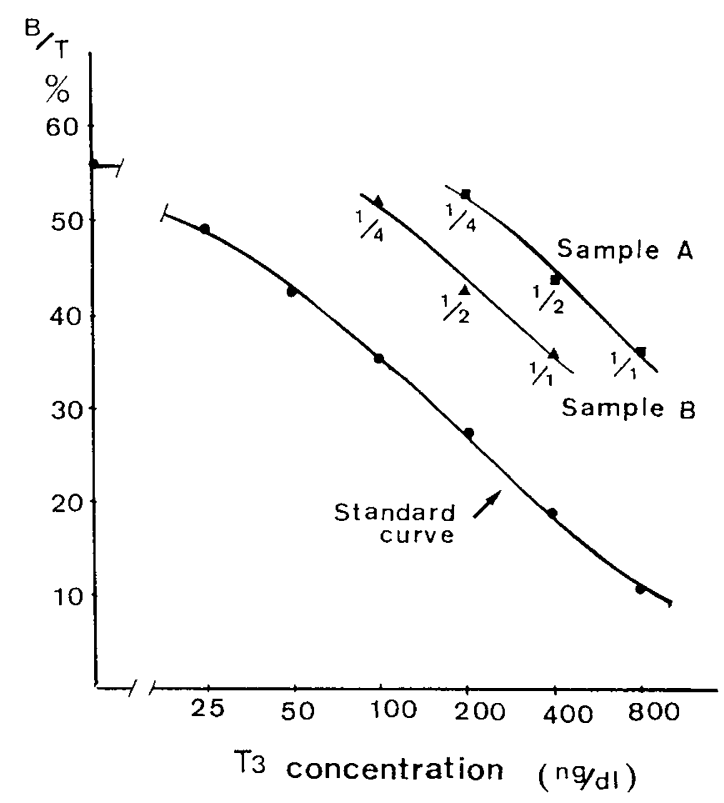

Fig. 1. Standard curve and dilution curve of samples in radioimmunoassay of milk $T_{3}$.

Table 3. Recovery of $T_{3}$ added to human milk in radioimmunoassay

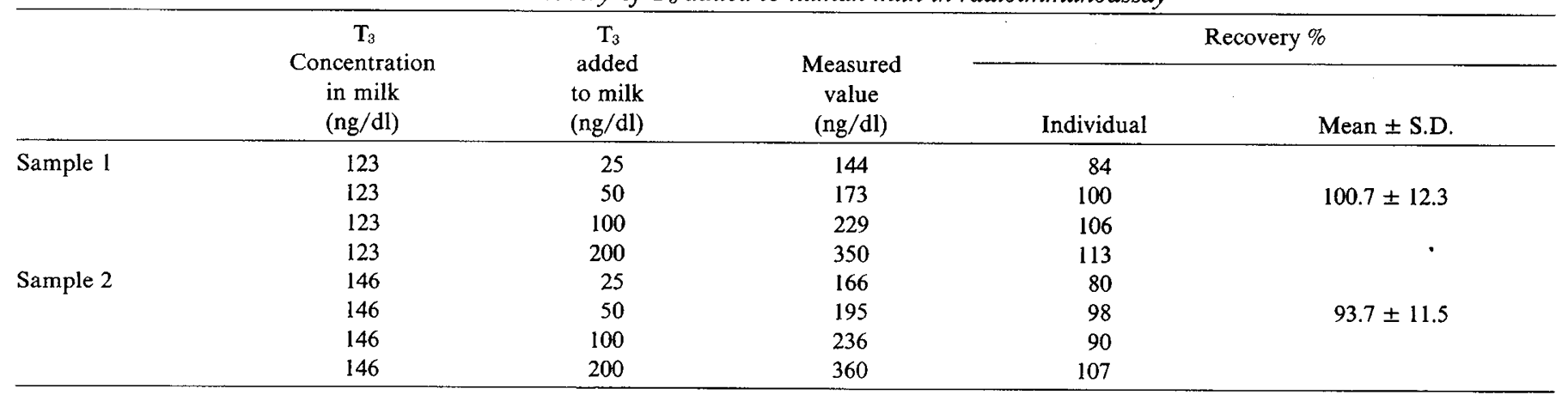


Table 4. Concentration of $T_{3}$ in serum and milk in puerperally lactating patients with thyroid disease

\begin{tabular}{|c|c|c|c|c|c|c|c|}
\hline \multirow[b]{2}{*}{ Case No. ${ }^{1}$} & \multirow{2}{*}{$\begin{array}{c}\text { Time of test } \\
\text { (postpartum } \\
\text { mo.) }\end{array}$} & \multicolumn{2}{|c|}{ Serum concentration ${ }^{2}$} & \multicolumn{2}{|c|}{ Milk concentration } & \multirow{2}{*}{$\begin{array}{c}\mathrm{T}_{3} \text { excretion } \\
\text { in milk } \\
\text { (ng/day) }\end{array}$} & \multirow[b]{2}{*}{$\begin{array}{l}\text { Serum } T_{3} \\
\text { to milk } T_{3} \\
\text { ratio }\end{array}$} \\
\hline & & $\begin{array}{c}\mathrm{T}_{3} \\
\text { (ng/d) }\end{array}$ & $\begin{array}{c}\text { Free } T_{3} \\
\text { index }\end{array}$ & $\begin{array}{c}\mathrm{T}_{3} \\
(\mathrm{ng} / \mathrm{dl})\end{array}$ & $\begin{array}{c}\text { Protein } \\
(\mathrm{mg} / \mathrm{dl})\end{array}$ & & \\
\hline 2 & 4 & 368 & 494 & 90 & 8.9 & 450 & 4.1 \\
\hline 3 & 2 & 202 & 222 & 26 & 8.9 & 156 & 7.8 \\
\hline 4 & $1 \frac{1}{2}$ & 147 & 136 & 72 & 9.9 & 396 & 2.0 \\
\hline 7 & 3 & 292 & 271 & 47 & 18.1 & 33 & 6.2 \\
\hline 8 & 1 & 185 & 178 & 90 & 11.2 & 342 & 2.1 \\
\hline 9 & 2 & 125 & 125 & 70 & 11.6 & 203 & 1.8 \\
\hline 10 & 1 & 175 & 162 & 95 & 11.1 & 380 & 1.8 \\
\hline 11 & $11 / 2$ & 175 & 211 & 111 & 9.3 & 200 & 1.6 \\
\hline 12 & 1 & 190 & 183 & 83 & 14.3 & 100 & 2.3 \\
\hline
\end{tabular}

${ }^{1}$ Cases No. 1-10 were patients with Graves' disease, cases No. 11-15 were patients with Hashimoto's disease and case No. 16 was a patient with simple goiter.

${ }^{2}$ Normal range $T_{3}, 110-200 \mathrm{ng} / \mathrm{dl} ;$ Free $\mathrm{T}_{3}$ index, $110-188$

${ }^{3}$ Total $\mathrm{T}_{3}$ excretion in milk per day was calculated as the product of $\mathrm{T}_{3}$ concentration in milk and the volume of milk secreted in $24 \mathrm{~h}$.

Table 5. Comparison of serum hormones between breast-fed and bottle-fed babies ${ }^{1}$

\begin{tabular}{lccl}
\hline & Breast-fed & Bottle-fed & \\
& $n=24$ & \multicolumn{1}{c}{$n=10$} & \\
\hline Thyrotropin $(\mu \mathrm{U} / \mathrm{ml})$ & $6.6 \pm 3.0$ & $5.8 \pm 3.5$ & N.S. $^{2}$ \\
$\mathrm{~T}_{4}(\mu \mathrm{g} / \mathrm{dl})$ & $11.4 \pm 2.4$ & $10.5 \pm 2.2$ & N.S. \\
Free $_{4}(\mathrm{ng} / \mathrm{dl})$ & $2.2 \pm 0.6$ & $1.9 \pm 0.5$ & N.S. \\
$\mathrm{T}_{3}(\mathrm{ng} / \mathrm{dl})$ & $218 \pm 40$ & $215 \pm 49$ & N.S. \\
\hline
\end{tabular}

${ }^{1}$ Values are mean \pm S.D.

${ }^{2}$ Mann Whiteny U test, N.S.: not significant.

ious levels of serum $\mathrm{T}_{3}$; however, we found no correlation between serum and milk $T_{3}$ levels. Daily $T_{3}$ excretion in milk also was not related to the serum $T_{3}$ concentration. Further studies are necessary to elucidate the mechanism of $\mathrm{T}_{3}$ excretion in milk.

In contrast with the report by Bode et al., Letarte et al. (3) recently reported that the breast feeding had no protective effect on congenital hypothyroidism. In the present study, breast feeding had no influence on the serum levels of thyrotropin and thyroid hormones of normal babies. The adequate dose of $T_{3}$ to maintain newborn hypothyroid babies in a euthyroid state was reported to be $50 \mu \mathrm{g}$ per sq $\mathrm{m}$ per day or more (7). We estimate the excretion of $T_{3}$ in milk was estimated as less than $1 \mu \mathrm{g}$ daily. This amount does not seem sufficient to ameliorate the results of mass screening and is adequate to prevent the deleterious effect of congenital hypothyroidism.

\section{REFERENCES AND NOTES}

1. Bode, H. H., Vanjonack, W. J., and Crawford, J. D.: Mitigation of cretinism by breast feeding. Pediatrics, 62: 13 (1978).

2. Brown Grant, K.: The iodine concentrating mechanism of the mammary gland. J. Physiol., 135: 644 (1957)

3. Letarte, J., Guyda, H., Dussault, J. H., and Glorieux, J.: Lack of protective effect of breast-feeding in congenital hypothyroidism: report of 12 cases. Pediatrics, 65: 703 (1980)
4. Lowry, O. H., Rosebrough, N. J., Farr, A. L., and Randall, R. J.: Protein measurement with the folin phenol reagent. J. Biol. Chem., 193: 265 (1951).

5. Man, E. B. and Benotti, J.: Butanol-extractable iodine in human and bovine colostrum and milk. Clin. Chem., 15: 1141 (1969).

6. Mitsuma, T., Colucci, J., Shenkman, L., and Hollander, C. S.: Rapid simultaneous radioimmunoassay for triiodothyronine and thyroxine in unextracted serum. Biochem. Biophys. Res. Comm., 46: 2107 (1972).

7. Petricciani, I. C., Aceto, T. Jr., Macgillivray, M. H., and Wagner, H.: Treatment of young cretins with triiodothyronine. Metabolism, 20:678 (1971).

8. Potter, G. D., Tong, W., and Chaikoff, I. L.: The metabolism of $I^{131}$-labeled iodine, thyroxine, and triiodothyronine in the mammary gland of the lactating rat. J. Biol. Chem., 234: 350 (1959).

9. Sack, J., Amado, O., and Lunenfeld, B.: Thyroxine concentration in human milk. J. Clin. Endocrinol. Metab.; 45: 171 (1977).

10. Sack, J., Frucht, H., Amado, O., Brish, M., and Lunenfeld, B.: Breast milk thyroxine and not cow's milk may mitigate and delay the clinical picture of neonatal hypothyroidism. Acta Pediatr. Scand., Suppl., 277: 54 (1979)

11. Sato, T., and Suzuki, Y.: Presence of triiodothyronine, no detectable thyroxine and reverse triiodothyronine in human milk. Endocrinol. Japon., 26: 507 (1979).

12. Shaw, W., Powell, J., Hubert, I. L., and Spierto, F. W.: Comparison of the interference of fatty acids in the competitive binding radioassay and radioimmunoassay for serum $T_{4}$. Clin. Chim. Acta, 73: 25 (1976).

13. Štrbák, V., Macho, L., Knopp, J., and Struhárová, L.: Thyroxine content in mother milk and regulation of thyroid function of suckling rats. Endocrinol. Exp., 8: 59 (1974).

14. Štrbák, V., Macho, L., Kovác, Škultétyová, M., and Michaličková, J.: Thyroxine (by competitive protein binding analysis) in human milk and cow milk and in infant formulas. Endocrinol. Exp., 10: 167 (1976).

15. Varma, S. K., Collins, M., Row, A., Haller, W. S., and Varma, K.: Thyroxine, tri-iodothyronine and reverse tri-iodothyronine concentrations in human milk. J. Pediatr., 93: 803 (1978)

16. Vigouroux, E., Rostaqui, N., and Fenerole, J. M.: Estimation of hormonal and non-hormonal iodine uptake from maternal milk in suckling rats. Acta Endocrinol., 93: 332 (1980).

17. We thank Misses Hatsue Miyoshi and Masako Kawai for secretarial assistance and Masao Ito for technical assistance.

18. Address requests for reprints to: Dr. K. Miyai, The Central Laboratory for Clinical Investigation, Osaka University Hospital, 1-1-50 Fukushima, Fukushima-ku, Osaka 553, Japan

19. This work was supported in part by a research grant from the Intractable Disease Division, Public Health Bureau, Ministry of Health and Welfare, Japan.

20. Received for publication March 23, 1982.

21. Accepted for publication August 30, 1982. 